\title{
What Is the Role of Neurotransmitter Systems in Cortical Seizures?
}

\section{P. MARE ̌̆, H. KUBOVÁ}

Department of Developmental Epileptology, Institute of Physiology, Academy of Sciences of the Czech Republic, v.v.i, Prague, Czech Republic

Received February 15, 2008

Accepted April 16, 2008

On-line May 13, 2008

\section{Summary}

Epileptic afterdischarges (ADs) elicited by electrical stimulation of sensorimotor cortical area were used as a model to study the role of neurotransmitter systems in cortical seizures in three age groups of developing rats. Drugs augmenting inhibition mediated by $\mathrm{GABA}_{\mathrm{A}}$ receptors were found to suppress $A D s$ in all age groups, their activity was usually more marked in younger than in 25-day-old rat pups. Drugs potentiating $\mathrm{GABA}_{B}$ receptors exhibit lower efficacy and more complicated developmental profile than $G A B A_{A}$-ergic drugs. Effects of an antagonist of $G A B A_{B}$ receptor marked prolongation of $A D s$ in all three age groups - suggest an important role of $\mathrm{GABA}_{B}$ receptors in arrest of cortical seizures. Drugs affecting glutamate receptors exhibit variable effects, usually better expressed in older animals than in 12-day-old ones. No specific role for ionotropic as well as metabotropic glutamate receptors could be predicted. Activation of adenosinergic inhibitory modulatory system also exhibited anticonvulsant action in the present model. All three neurotransmitter systems probably participate in mechanisms of generation, maintenance and arrest of cortical seizures.

\section{Key words}

Cortical epileptic afterdischarges - GABA - Glutamate • Pharmacology • Immature rats

\section{Corresponding author}

P. Mareš, Department of Developmental Epileptology, Institute of Physiology, Academy of Sciences of the Czech Republic, Vídeňská 1083, CZ-14220 Prague 4, Czech Republic. E-mail: maresp@biomed.cas.cz

\section{Introduction}

Nearly all epileptic seizures are characterized by predominance of excitation over inhibition either simultaneously in many brain structures (primary generalized convulsive seizures) or in a part of the brain (partial, focal seizures). Potentiation of GABAergic inhibition is the main mechanism of action of many antiepileptic drugs (Jones-Davis and Macdonald 2003, Rogawski and Loscher 2004, Meldrum and Rogawski 2007, White et al. 2007). Sites of action of individual drugs are different, major mechanisms of action are presented in Figure 1. Opposite way, i.e. suppression of excitatory transmission using antagonists of ionotropic glutamate receptors does not represent the main mechanism of action in any of the current clinically used antiepileptic drugs because of serious side effects. Antagonism of excitatory amino acid receptors represents only a minor mechanism in some antiepileptics (topiramate, felbamate, lamtotrigine?) but excellent anticonvulsant action of many experimental drugs represent a reason for further studies in this field (Chapman 1998). Recently the attention was shifted to metabotropic glutamate receptors mainly because unwanted side effects of anticonvulsant doses of drugs influencing these receptors are not so serious as those of antagonists of ionotropic glutamate receptors therefore their therapeutic index is better (Doherty and Dingledine 2002, Moldrich et al. 2003). Again, individual drugs act at different sites of ionotropic and/or metabotropic glutamate receptors and a schematic representation is in Figure 2. Majority of data concerning the mechanisms of action at the level of receptors was obtained in hippocampus in vivo as well as in vitro. In contrast to the 


\section{Drugs affecting GABAergic system}

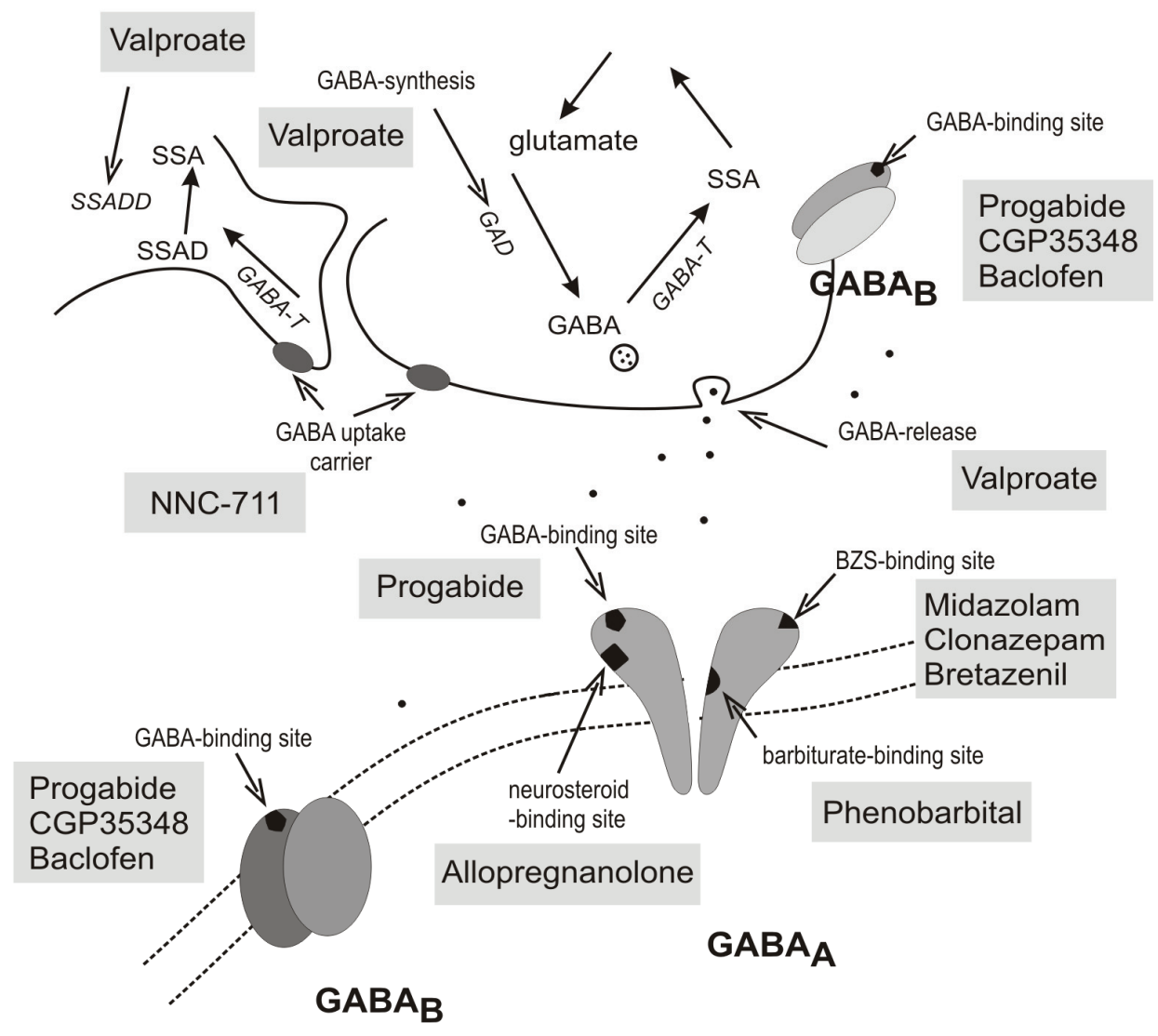

Fig. 1. Schematic drawing illustrates different sites of action (pointed by arrows) of GABAergic drugs tested in a model of cortical epileptic afterdischarges. Most of tested drugs act directly as agonists of $\mathrm{GABA}_{\mathrm{A}}$ receptors (benzodiazepines, barbiturates). Baclofen and CGP35348 interact with $\mathrm{GABA}_{B}$ receptors. GABA analogue progabide acts as agonist of both $\mathrm{GABA}_{A}$ and $\mathrm{GABA}_{B}$ receptors. NNC-711 increases concentration of GABA due to blockade of GABA uptake carrier. Antiepileptic drug valprote interacts with GABAergic system at several sites: 1) increases release of GABA from presynaptic terminals, 2) inhibits SSAD dehydrogenase, 3 ) if insufficient quantities of GABA are present, GAD is activated due to the lack of end-product inhibition resulting from a lower concentration of the end-product, succinic acid. Abbreviations: GABAT - GABA transaminase; GAD - L-glutamic acid decarboxylase; SSAD - succinic semialdehyde; SSA succinic acid; SSADD - succinic semialdehyde dehydrogenase.

role of hippocampus in epilepsies of adult patients childhood epilepsies are characterized by a dominant involvement of the neocortex. Therefore we elaborated a model of cortical seizures elicited by rhythmic electrical stimulation. Our model of cortical epileptic afterdischarges is based on similar model of Voskuyl et al. $(1989,1992)$. These authors focused their attention of events during stimulation of sensorimotor areas of both hemispheres. Our modification uses stimulation of sensorimotor area of one hemisphere and we record not only immediate effects of stimulation (movements directly bound to individual stimuli) but also epileptic afterdischarges. Three more phenomena could be evaluated: afterdischarges characterized by spike-andwave rhythm in the EEG, clonic seizures accompanying these afterdischarges and transition into another type of afterdischarges characterized by fast spikes and/or delta waves with concomitant epileptic automatisms (wet dog shakes, elements of orienting reaction) (Mareš et al. 2002a, Mareš and Kubová 2006).

For pharmacological studies we are using experimental paradigm with repeated stimulation with the same stimulation intensity which is suprathreshold for spike-and-wave type of afterdischarges. The first afterdischarge is always a control one, only after it the drug is injected and stimulation is repeated three to five more times in fixed intervals (10 or 20 min according to the pharmacokinetics of individual drugs). EEG pattern of afterdischarges, their duration, prolongation or shortening with repeated stimulations, and possible 


\section{Drugs affecting glutamatergic system}

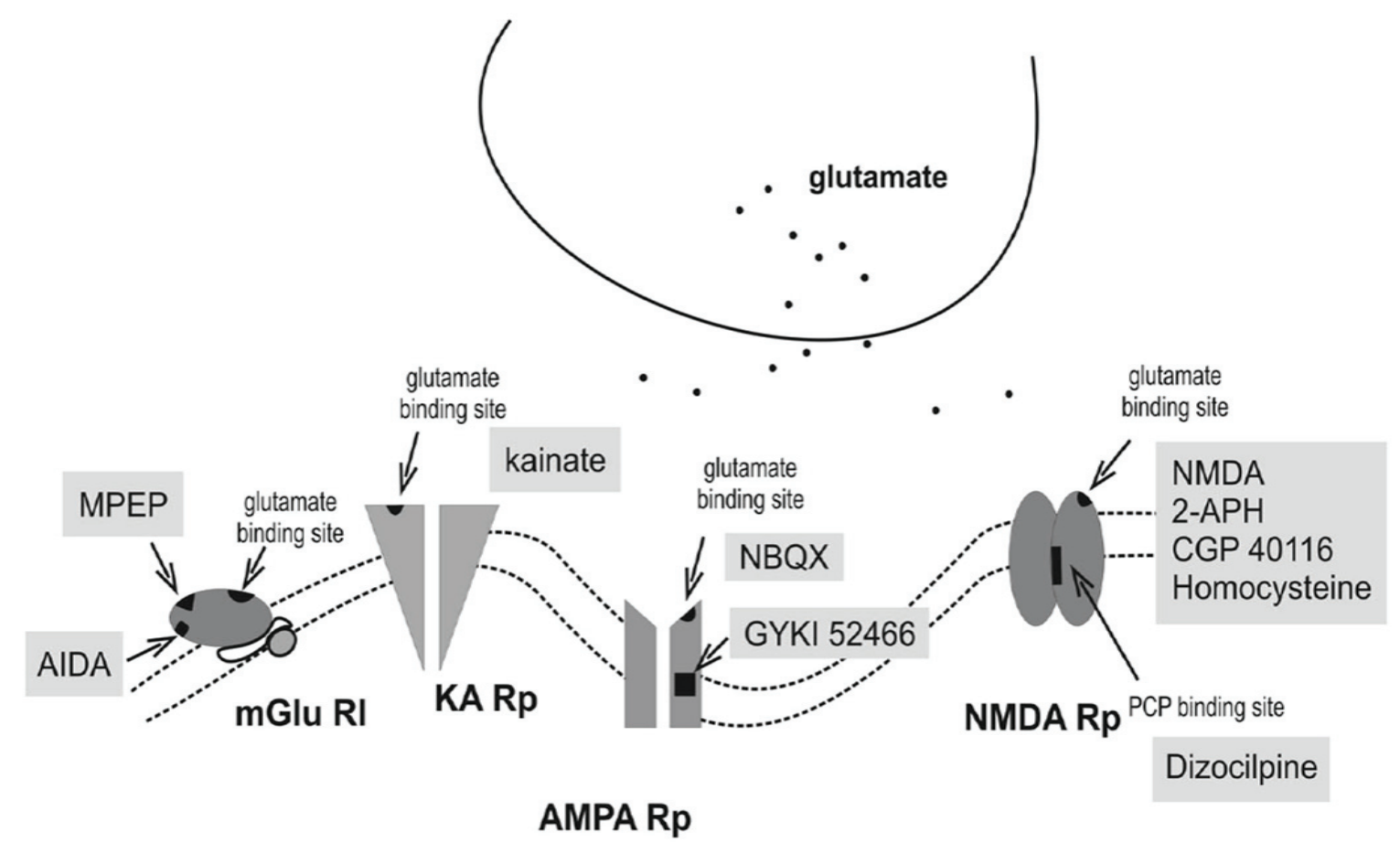

Fig. 2. Mechanisms of actions of drugs affecting glutamatergic system tested in a model of cortical epileptic afterdischarges. NMDA, 2-APH and homocysteine are competitive agonists of NMDA receptors. Dizocilpine (MK 801) acts as non-competitive antagonist, 2-APH and CGP 40116 as competitive antagonists of NMDA receptors. NBQX is competitive and GYKI 52466 non-competitive antagonist of AMPA receptor and kainate acts as competitive agonist of KA receptors. MPEP and AIDA allosterically inhibit metabotropic receptor subtypes mGluR5 and mGluR1, respectively. Abbreviations: NMDA - N-methyl-D-aspartate, 2-APH - 2-amino-7-phosphonoheptanoic acid, AMPA - alpha-amino-3-hydroxy-5-methyl-4-isoxazole propionic acid.

transition to limbic type are always evaluated.

Cortical epileptic afterdischarges can be induced in laboratory rats reliably since the age of 12 days (Mareš et al. 2002a) therefore this is the youngest group in our experiments. Two older groups are also studied - 18- and 25-day-old animals. There are typical developmental features of cortical afterdischarges: spike-and-wave rhythm can be recorded in 18- and 25-day-old rats, 12-day-old pups generate rhythmic delta waves (Fig. 3). Prolongation of afterdischarges with repeated stimulations is marked in 12-dayold rats and outlined in 18-day-old ones under control conditions (Fig. 3).

Our attention was focused on the two main neurotransmitter systems - those using gammaaminobutyric acid and glutamate as their mediators. In addition, our review presents also some data on another important system - inhibitory modulation mediated by adenosine. Role of adenosinergic system in epilepsy and possible therapeutic use of drugs influencing this system was recently reviewed (Boison 2006, 2008).

\section{Drug effects in individual neurotransmitter systems}

The effect of particular drugs on cortical epileptic discharges are shown in Table 1.

\section{Effects of drugs influencing GABAergic inhibition}

There are many established antiepileptic drugs with potentiation of GABAergic inhibition as the main mechanism of action. Phenobarbital (5-ethyl-5phenylbarbituric acid - Polášek et al. 1996), benzodiazepines clonazepam (5-(2-chlorophenyl)-1,3dihydro-7-nitro-2H-1,4-benzodiazepin-2-one - Kubová et al. 1993) and midazolam (8-chloro-6-(2-fluorophenyl)-1methyl-4H-imidazo-[1,5-a][1.4]-benzodiazepine Kubová et al. 1993) and valproate (Polášek et al. 1996) were tested in this experimental paradigm. In addition, a partial benzodiazepine agonist bretazenil (Ro 16-6028, an imidazobenzodiazepine - Mareš and Šlamberová 2006a), positive allosteric modulators of $\mathrm{GABA}_{\mathrm{A}}$ receptors neuro-

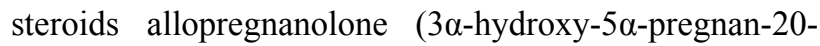



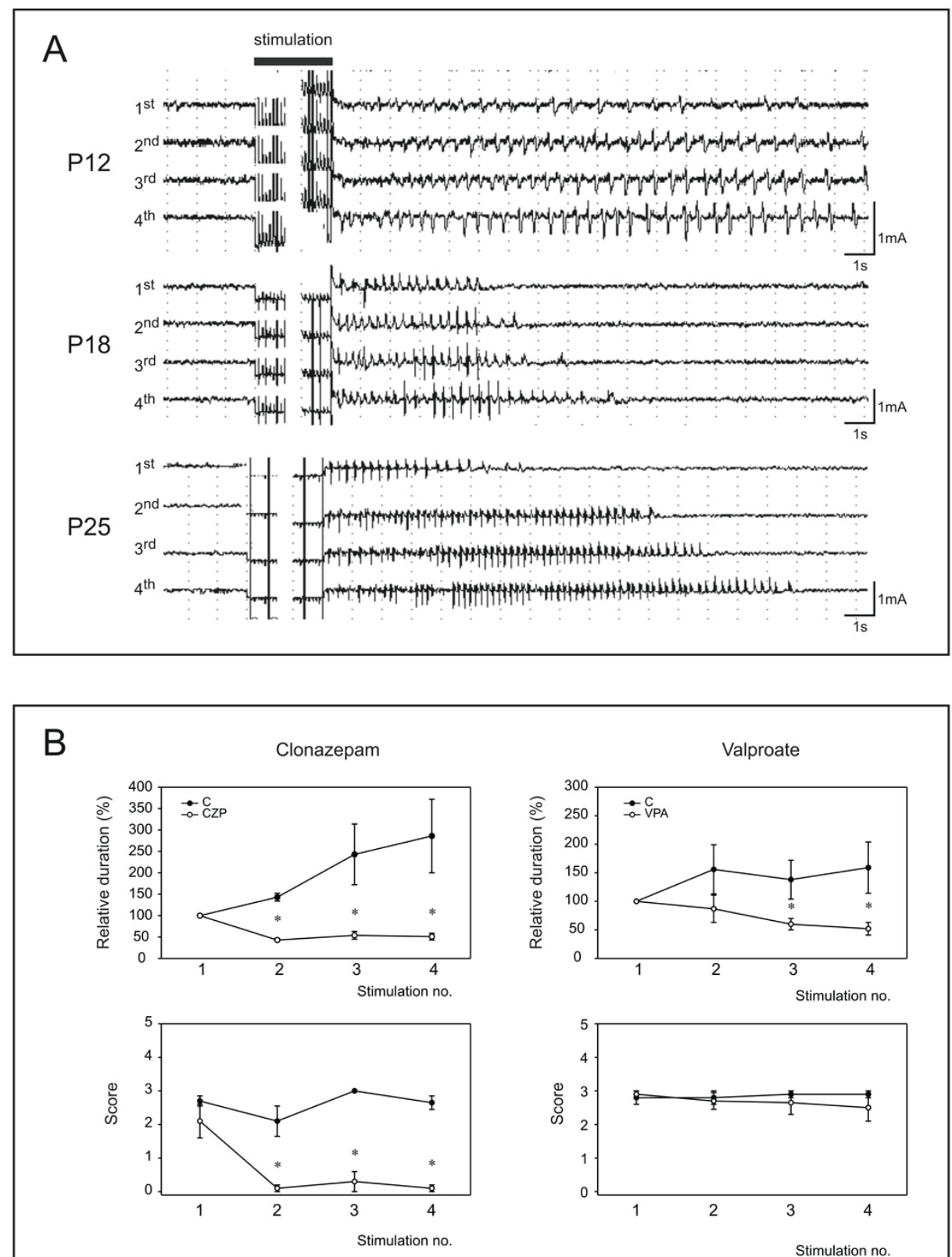

Fig. 3. Upper part: original recordings of four subsequent epileptic afterdischarges from sensorimotor region symmetrical to stimulated area in 12-, 18- and 25-day-old rats (from top to bottom). Each recording starts with the last $3 \mathrm{~s}$ before stimulation, then the first second of stimulation is represented. After an interruption (13 s of stimulation are omitted) the last second of stimulation and $18 \mathrm{~s}$ after the end of stimulation are presented. Lower part: Effects of clonazepam $(0.5 \mathrm{mg} / \mathrm{kg}$, left two graphs) and valproate (200 $\mathrm{mg} / \mathrm{kg}$, right graphs) on duration (upper graphs) and seizure severity expressed as a score (lower graphs) in 12-day-old rats compared to control animals injected with solvent. Abscissae: four stimulations, drugs were injected after the end of the first AD. Ordinates: upper graphs relative duration (duration of the first, predrug $A D$ is taken as 100 $\%)$ of ADs; lower graphs: fivepoint scale for severity of seizures. Asterisks indicate significant differences between corresponding control and drug ADs. one) and pregnanolone ( $3 \alpha$-hydroxy-5 $\beta$-pregnan-20-one) (Mareš 2005), an agonist on both $\mathrm{GABA}_{\mathrm{A}}$ and $\mathrm{GABA}_{\mathrm{B}}$ receptors progabide (4-[\{(4-chlorophenyl)(5-fluoro-2hydroxyphenyl)methylene $\}$ amino] butanamide - Polášek et al. 1996) and a GABA uptake inhibitor NNC-711 (1(2-([(diphenylmethylene) amino] oxy) ethyl) 1,2,4,6tetrahydro-3-pyridine-carboxylic acid hydrochloride Bernášková et al. 1999), were also studied. To differentiate the action on $\mathrm{GABA}_{\mathrm{B}}$ receptors an agonist baclofen ( $\beta$-chlorophenylGABA) and a $\mathrm{GABA}_{\mathrm{B}}$ receptor antagonist CGP35348 were also studied (Mareš and Šlamberová 2006b). Generally, drugs potentiating inhibition mediated by $\mathrm{GABA}_{\mathrm{A}}$ receptors (benzodiazepines, phenobarbital, valproate, neurosteroids) were found to suppress cortical epileptic afterdischarges in all three age groups studied (Fig. 3). Dose-dependent action was seen in all these drugs with the exception of bretazenil. In contrast, movements directly bound to stimulation were suppressed only by phenobarbital and less efficiently by valproate. Intensity of clonic seizures accompanying spike-and-wave type of ADs was diminished by all these drugs, especially by clonazepam (Fig. 3) and midazolam. Suppression of convulsions with these two benzodiazepines was so marked that after the highest doses used was it possible to register short $\mathrm{ADs}$ in the EEG without any motor correlate. Expected $U$ shape curve of dose-effect relationship for a partial benzodiazepine agonist 
Table 1. Effects of drugs on cortical epileptic afterdischarges.

\begin{tabular}{|c|c|c|c|c|c|c|}
\hline \multirow[t]{2}{*}{ Age (postnatal days) } & \multicolumn{2}{|c|}{ P12 } & \multicolumn{2}{|c|}{ P18 } & \multicolumn{2}{|c|}{ P25 } \\
\hline & EEG & behavior & EEG & behavior & EEG & behavior \\
\hline Midazolam & + & + & + & + & + & + \\
\hline Clonazepam & + & + & + & $?$ & + & ++ \\
\hline Bretazenil & $(+)$ & + & + & + & ++ & + \\
\hline Phenobarbital & + & + & + & + & + & + \\
\hline Valproate & + & \pm & + & + & + & + \\
\hline Progabide & \pm & - & + & + & + & + \\
\hline Baclofen & \pm & - & \pm & + & + & + \\
\hline$N N C-711$ & $(+)$ & - & + & + & ++ & + \\
\hline Allopregnanonolone & $(+)$ & - & \pm & - & + & - \\
\hline Pregnanolone & + & - & $\mathrm{nt}$ & $\mathrm{nt}$ & + & - \\
\hline $2-A P H$ & $?$ & - & - & - & + & \pm \\
\hline$C G P 40116$ & + & + & + & + & + & + \\
\hline Dizocilpine & $(+)$ & - & + & \pm & + & + \\
\hline$N B Q X$ & + & + & + & + & + & + \\
\hline GYKI 52466 & $(+)$ & \pm & + & \pm & + & + \\
\hline$M P E P$ & + & - & + & - & + & - \\
\hline$A I D A$ & \pm & - & \pm & - & - & - \\
\hline 2-chloroadenosine & + & \pm & + & (R) & $\pm(\mathrm{R})$ & + \\
\hline$C G P 35348$ & A & - & A & - & A & - \\
\hline$N M D A$ & AA & $\operatorname{ch}(\mathrm{FS})$ & - & - & \pm & - \\
\hline Homocysteine & $\mathrm{AA}$ & $\operatorname{ch}(\mathrm{FS})$ & $\mathrm{AA}$ & - & $\mathrm{AA}$ & $\operatorname{ch}(\mathrm{GTCS})$ \\
\hline Kainic acid & AA & - & AAA & $\operatorname{ch}($ aut $)$ & $\mathrm{AA}$ & $\operatorname{ch}($ aut $)$ \\
\hline Aminophylline & AA & $\operatorname{ch}(\operatorname{mix})$ & $\mathrm{AA}$ & $\operatorname{ch}(\operatorname{mix})$ & $\mathrm{AA}$ & - \\
\hline
\end{tabular}

P12, P18, P25 - age in days; EEG - electrocorticographic seizures; behavior - clonic convulsions;,+++ suppression; $(+)$ block of progressive prolongation; non-significant change; - not affected; nt - not tested; $(R)$ - rebound, i.e.prolongation of Ads after initial suppression; AAA, AA, A - augmented; $c h(F S)$ - change to flexion seizures; $c h(m i x)$ change to limbic type of ADs; $\operatorname{ch}(\mathrm{GTCS})$ - change to generalized tonic-clonic seizures; ch(aut) - change to automatisms

bretazenil was only outlined in 18-day-old rats. It is in agreement with doubts casted on the classification of this drug as partial agonist. Drugs influencing inhibition mediated by both $\mathrm{GABA}_{\mathrm{A}}$ and $\mathrm{GABA}_{\mathrm{B}}$ receptors (progabide and NNC-711) exhibited different spectrum of effects. They were able to diminish intensity of both movements elicited directly by stimulation and clonic seizures in 18- and 25-day-old rats but not in 12-day-old ones. Similar developmental change was registered as EEG ADs are concerned: 12-day-old rats exhibited only suppression of progressive prolongation seen in controls whereas 18- and 25-day-old groups demonstrated shortening of ADs. Activation of $\mathrm{GABA}_{\mathrm{B}}$ receptors could explain the effect on stimulation-bound movements because baclofen exhibited the same action as progabide and NNC-711, some similarity could be seen also in effects on clonic seizures. What is markedly different is the action on electrocorticographic ADs; they were shortened in 12- and 25- but not in 18-day-old rats.

Marked prolongation of ADs without any effect on motor phenomena observed after $\mathrm{GABA}_{\mathrm{B}}$ receptor antagonist CGP35348 (P-[3-aminopropyl]-P-diethoxymethylphosphinic acid) speaks in favor of the role of inhibition mediated by $\mathrm{GABA}_{\mathrm{B}}$ receptors in arrest of cortical ADs. It is in contrast with our pilot experiments with bicuculline, a competitive antagonist of $\mathrm{GABA}_{\mathrm{A}}$ receptors. Duration of ADs was nearly untouched by this antagonist.

Potentiation of GABAergic inhibition is effective in the model of cortical epileptic afterdischarges. As inhibition mediated by $\mathrm{GABA}_{\mathrm{A}}$ receptors is concerned, only quantitative changes were 
found during development. Effects of drugs influencing $\mathrm{GABA}_{\mathrm{B}}$ receptors are more complicated and qualitative differences of action were found comparing different developmental stages.

Effects of drugs influencing excitatory amino acid receptors

Antagonists of NMDA type of glutamate receptors exhibit anticonvulsant action against cortical ADs but these effects vary quantitatively as well as qualitatively according to age (Šlamberová and Mareš 2005). Competitive antagonist of NMDA receptors CGP40116 (D-(E(-2-amino-4-methyl-5-phosphono-3pentenoic acid) was most potent among the three tested drugs. It decreased intensity of both motor phenomena and shortened the ADs. Another competitive antagonist 2-APH (2-amino-7- phosphonoheptanoic acid) did not influence movements elicited by stimulation, anticonvulsant effects on $\mathrm{AD}$ duration and intensity were significant only in 25-day-old rats. Noncompetitive antagonist dizocilpine (MK-801, (+)-5-methyl-10,11dihydro-5Hdibenzo[a,d]cyclohepten-5,10-imine hydrogen maleate) exhibited low potency in 12-day-old rats - only progressive prolongation of ADs was blocked. The effects in the two older groups were more marked. ADs were shortened and intensity of clonic seizures decreased. Movements bound to stimulation were affected only in 18-day-old rats.

AMPA receptor antagonists exhibited anticonvulsant effects only in high doses (NBQX, 2,3dihydroxy-6-nitro-7-sulfamoyl-benzo(f)quinoxaline, 60 and $90 \mathrm{mg} / \mathrm{kg}$ - Mareš et al. 1997, GYKI 52466, (1-(4-aminophenyl)-4-methyl-7,8-methylenedioxy-5H-

2,3-benzodiazepine, $20 \mathrm{mg} / \mathrm{kg}$ - Kubová et al. 1997). There was a developmental difference between the two antagonists. NBQX exhibited strongest effects in 12-dayold rats whereas GYKI 52466 in 18- and 25-day-old ones. Either drug influenced motor phenomena as well as ADs.

MPEP (2-methyl-6-(phenylethynyl)-pyridine), an antagonist of mGluR5 subtype of metabotropic glutamate receptors, did not affect motor phenomena but it was able to decrease duration of ADs (Lojková and Mareš 2005). This effect was observed only after high doses (20 and $40 \mathrm{mg} / \mathrm{kg}$ ) and it was only transient in 18and 25-day-old rats. This effect lasted longer in 12-dayold rat pups and there was no tendency to prolongation of ADs with repeated stimulations. Similar effects were found with another mGluR5 antagonist MTEP (3-[(2- methyl-1,3-thiazol-4-yl) ethynyl]-pyridine) whereas a specific antagonist of mGluR1 AIDA (1-aminoindan-1,5dicarboxylic acid) was without significant effects (Lojková et al., submitted).

All up to now studied agonists of glutamate receptors potentiate cortical epileptic afterdischarges but their action is different (Mareš et al. 2002b). Doses of the agonist had to be modified according to the age to have subconvulsant doses of similar potency in all three age groups. None of the tested agonists affected movements directly elicited by stimulation. N-methyl-D-aspartate (NMDA) as a prototypic agonist of one class of ionotropic glutamate receptors exhibited marked action only in 12-day-old rats. Duration of ADs was prolonged and pattern of convulsions was changed from clonic to flexion (emprosthotonic) seizures typical for the action of convulsant doses of NMDA in this age group (Mareš and Velíšek 1992). No effects were observed in 18- and 25day-old animals. Homocysteine, a drugs with agonistic action on NMDA receptors and other additional actions, increased the duration of ADs in all three age groups. It markedly augmented transition of the spike-and-wave type of ADs into the limbic one, this effect was most common in 18-day-old rats. Such transition is rather exceptional under control conditions. Pattern of convulsions was changed differently according to the age: the same transition into flexion seizures as with NMDA was observed in 12-day-old rats, 18- day-old animals exhibited mostly automatisms belonging to the limbic type of seizures. Unique change was recorded in 25-dayold rats where the higher dose of homocysteine led to a transition from clonic seizures of head and forelimb muscles to generalized tonic-clonic seizures - usually after the fourth stimulation. Kainic acid, a prototypic agonist of one type of nonNMDA glutamate receptors, increased duration of ADs in all three age groups leaving intact the motor pattern of seizures. Subconvulsant doses of kainic acid used in our experiments elicited an EEG pattern of low amplitude fast spikes. This pattern was always masked by stimulation and ADs and it reappeared after the end of ADs.

\section{Effects of drugs acting at adenosine receptors}

We decided to study this inhibitory modulatory system mainly because of work of Dragunow (1986) who gave to this system a label of endogenous anticonvulsant system.

Adenosine receptor agonist 2-chloroadenosine diminished the intensity of movements connected with 
stimulation in 18- and to a lesser degree in 25-day-old rats. Duration of ADs elicited immediately $(5 \mathrm{~min})$ following the administration of 2-chloroadenosine was diminished in all three age groups. Intensity of this effect decreased with age, it was preserved for the next $\mathrm{AD}$ in 12-day-old rats only. On the contrary, 18- and 25-day-old animals exhibited marked prolongation of the fourth and/or third and fourth AD, respectively, as a rebound effect (Pometlová and Mareš - in preparation).

Aminophylline is a mixture of theophylline and ethylenediamine (85:15) -theophylline is an antagonist of adenosine receptors. Aminophylline did not affect motor phenomena but markedly increased duration of ADs mostly due to an increased transition from initial spikeand-wave into the limbic type of ADs. This type was, of course, accompanied by epileptic automatisms (Bernášková and Mareš 2000).

\section{Cortical phenomena}

To summarize the data and try to answer the question about neurotransmitter role in cortical epileptic afterdischarges in developing brain is it difficult to differentiate between nonspecific effects (e.g. effects of drugs potentiating $\mathrm{GABA}_{\mathrm{A}}$-ergic inhibition) and specific effects on elementary processes (e.g. effect of $\mathrm{GABA}_{\mathrm{B}}$ receptor antagonist on duration of $\mathrm{ADs}$ ). It is necessary to take into account three different phenomena:

\section{Movements during stimulation}

These movements were reliably suppressed in all age groups only by the $40-\mathrm{mg} / \mathrm{kg}$ dose of phenobarbital. Some drugs were able to decrease intensity of stimulation-bound movements in 18- and 25-day-old rats: drugs with a positive action on inhibition mediated by $\mathrm{GABA}_{\mathrm{B}}$ receptors baclofen, progabide, and NNC-711, and nonNMDA receptor antagonists NBQX and GYKI 52466. Similar action but less expressed was observed with some benzodiazepines. These movements were not potentiated by $\mathrm{GABA}_{\mathrm{B}}$ antagonist or glutamate receptor agonists studied. In spite of this last statement, participation of $\mathrm{GABA}_{\mathrm{B}}$ and nonNMDA (AMPA) receptors can be taken as a mechanism. Exact site where these two systems act remains to be studied. $\mathrm{GABA}_{\mathrm{B}}$ receptor agonist baclofen is clinically used to relieve spasticity and it can influence motor systems at many levels starting with motor cortex up to spinal cord. There are more data for the role of AMPA receptors in the motor system. High incidence of these receptors was demonstrated in cerebral cortex and basal ganglia not only in adult but also in developing rats (Petralia et al. 1992, Spreafico et al. 1994). Therefore an effect on the cortico-striatal pathway, an initial part of extrapyramidal system, has to be presumed.

\section{Spike-and-wave afterdischarges}

EEG pattern of spike-and-wave rhythm can be taken as an epiphenomenon. It forms a part of substantially different models of epileptic seizures model of generalized absence seizures induced by low doses of pentylenetetrazol and model of myoclonic seizures elicited by rhythmic cortical stimulation described in this review. These two electroencephalographically similar patterns were differently influenced by drugs acting at $\mathrm{GABA}_{\mathrm{B}}$ receptors (Mareš and Šlamberová 2006b) in spite of the presumed thalamocortical generation of all types of these rhythmic activities (Steriade 2007).

Suppressive action of all drugs acting positively at $\mathrm{GABA}_{\mathrm{A}}$ receptors, NMDA receptor antagonist CGP 40116 and adenosine receptor agonist 2-chloroadenosine is probably a nonspecific action. Moderate action of progabide and NNC-711 - block of prolongation in 12day-old rats and shortening of ADS in 18- and 25-day-old rats might be ascribed to their potentiation of $\mathrm{GABA}_{B}$ system. Their effects are similar to those of baclofen (Mareš and Šlamberová 2006b). Extreme prolongation of ADs induced by GABA $_{B}$ receptor antagonist CGP 35348 in all three age groups suggests a role of inhibition mediated by $\mathrm{GABA}_{\mathrm{B}}$ receptors in arrest at least cortical seizures.

\section{Clonic seizures}

Generally, clonic seizures accompanying spikeand-wave ADs are more easily influenced than similar motor pattern directly bound to stimulation of sensorimotor cortical area. Intensity of clonic seizures was diminished after all drugs potentiating $\mathrm{GABA}_{\mathrm{A}}$ or $\mathrm{GABA}_{\mathrm{B}}$-mediated inhibition. Extremely strong effects of clonazepam and probably some other benzodiazepines remains to be explained. Glutamate receptor antagonists are able to diminish intensity of clonic seizures but there are differences even in the same class of antagonists (NMDA receptor antagonists). We are prone to take also the effects on seizures as nonspecific exerted at many sites in the central nervous system.

An unexpected phenomenon was the transition of spike-and-wave type of ADs into limbic type after administration of two drugs with different mechanisms of 
action - homocysteine and aminophylline. Under control conditions transition into limbic type of ADs appears only after high stimulation intensities (Mareš et al. 2002a). In all above quoted experiments the intensity of stimulation current was relatively low because we tried to elicit spike-and-wave type of ADs. This transition was rather exceptional in control animals in our experiments. The key structure for this transition is with high probability thalamic mediodorsal nucleus (Bertram et al. 2001) therefore the analysis must focus on this nucleus.

\section{Developmental aspects}

There are many maturational factors which can modify the effect of individual drugs on parameters of cortical afterdischarges. The immature brain is highly excitable in order to support synaptogenesis and increased neuronal plasticity. Such increase of excitability is crucial for normal development but it can also participate in easy generation of seizures in the immature brain. In present model of cortical afterdischarges long duration of afterdischarges observed in P12 rats (see Fig. 3) is one of many indices of increased ability to generate seizures at early stages of postnatal development.

The three age groups studied cover relatively long developmental period. Twelve-day-old rats correspond to human early postnatal stage and sexual maturation in rats start around postnatal day 35 (corresponding to approximately 12-14 years in children). There are marked changes in both major neurotransmitter systems, gutamatergic and GABAergic, during the first three weeks of postnatal life in rats (for review Sanchez and Jensen 2001). GABAergic system matures during the third and fourth postnatal week. The molecular composition of $\mathrm{GABA}_{\mathrm{A}}$ receptors is developmentally regulated, but changes in the anticonvulsive effects of $\mathrm{GABA}_{\mathrm{A}}$ receptor agonists are not too big. Efficacy of benzodiazepines and phenobarbital exhibits only a moderate decrease during postnatal development in spite of the fact that benzodiazepine binding peaks at 4th postnatal week. $\mathrm{GABA}_{\mathrm{B}}$ receptor binding in rat brain increases during development and peeks in area specific manner during the third week of life. In the neocortex and thalamus there is the overshoot of receptor expression at P14. Thus, stable effects of drugs interacting with $\mathrm{GABA}_{\mathrm{B}}$ receptors in model of cortical epileptic afterdischrages don't correlate with age-related differences of receptor expression. It has to be however emphasized that $\mathrm{GABA}_{\mathrm{B}}$ receptors are located both pre and postsynaptically. In the hippocampus, presynaptic effects of $\mathrm{GABA}_{\mathrm{B}}$ receptors occur earlier than postsynaptic effects, what may increase synaptic excitability due to suppression of GABA release. In contrast to stable effects of $\mathrm{GABA}_{\mathrm{A}}$ agonists, efficacy of NNC-711, an inhibitor of GAT-1, increases with age. This drug increases the concentration of GABA in the brain tissue and therefore its administration leads to activation of both $\mathrm{GABA}_{A}$ and $\mathrm{GABA}_{B}$ receptors. Also activity of GAT1 changes with age and brain structure. It is present early in development and expression of GAT1- increases markedly after the P10 in various brain areas (Kubová 1999). Thus, complicated development of both systems together with developmental changes of GABA transporters may participate in age-specific effects of this drug.

There is relative overexpression of glutamate receptors during the first weeks of life. NMDA receptor density peeks in the neocortex and hippocampus at the end of the first week of life whereas maximal density of AMPA receptors appears during the second week. Kainate receptor density increases gradually over the first weeks of life. Taken together, the first 2-3 postnatal weeks represent period when glutamate receptors are overshoot and it can be speculated that effects of glutamate receptor antagonists will be most prominent at this age. Present data however demonstrate that this is not always a case. Both AMPA and NMDA receptor antagonists (GYKI 52466, 2-APH and dizocilpine) are most efficient in P25 rats. On the other hand, effects of NBQX do not change with age. These data suggest that other factors than receptor density can be involved in agerelated changes of efficacy of tested receptor antagonists. Among them changes in receptor composition can play an important role. It is well known that molecular composition of glutamate receptors is developmentally regulated and changes in receptor subunit composition can affect binding of some drugs to the receptor. In addition, it has to be emphasized that changes in receptor expression as well as composition can vary among individual brain structures. Even though present model mainly characterize effects of tested drugs on cortical excitability, also other structures (at least thalamus, basal ganglia, limbic structures) are involved in spread of epileptic activity and consequently in EEG and motor afterdischarge pattern. Thus, both area and age related differences in glutamate receptor properties can be involved in final effects of tested drugs.

Effects of all systematically administered drugs are also affected by pharmacokinetics and many pharmacokinetic parameters change significantly during 
postnatal development. Some quantitative differences seen between individual age groups (like duration of protective effects or lower sensitivity to drug effects) may be related to maturation of metabolic pathways (leading to increased excretion) or to maturation of blood brain barrier limiting penetration of tested drug into the brain. Direct data on age related changes of pharmacokinetics of tested drugs are either very limited or not available.

\section{Conflict of Interest}

There is no conflict of interest.

\section{Acknowledgements}

This study was supported by the project LC554 of the Ministry of Education of the Czech Republic and by a research project AV0Z 50110509.

\section{References}

BERNÁŠKOVÁ K, MAREŠ P: Proconvulsant effect of aminophylline on cortical epileptic afterdischarges varies during ontogeny. Epilepsy Res 39: 183-190, 2000.

BERNÁŠKOVÁ K, ŠLAMBEROVÁ R, MAREŠ P: GABA uptake blocker NNC 711 exhibits marked anticonvulsant action in two cortical epileptic models in immature rats. Epilepsia 40: 1184-1189, 1999.

BERTRAM EH, MANGAN PS, ZHANG D, SCOTT CA, WILLIAMSON JM: The midline thalamus: alterations and a potential role in limbic epilepsy. Epilepsia 42: 967-978, 2001.

BOISON D: Adenosine kinase, epilepsy and stroke: mechanisms and therapies. Trends Pharmacol Sci 27: 652-658, 2006.

BOISON D: Adenosine as a neuromodulator in neurological diseases. Curr Opin Pharmacol 8: 2-7, 2008.

CHAPMAN AG: Glutamate receptors in epilepsy. Progr Brain Res 116: 371-383, 1998.

DOHERTY J, DINGLEDINE R: The roles of metabotropic glutamate receptors in seizures and epilepsy. Curr Drug Targets CNS Neurol Disord 1: 251-260, 2002.

DRAGUNOW M: Endogenous anticonvulsant substances. Neurosci Biobehav Rev 10: 229-244, 1986.

JONES-DAVIS DM, MACDONALD RL: GABA $A$ receptor function and pharmacology in epilepsy and status epilepticus. Curr Opin Pharmacol 3: 12-18, 2003.

KUBOVÁ H: NNC-711: an inhibitor of GABA uptake with selective affinity to GAT-1. CNS Drug Rev 5: 317-330, 1999.

KUBOVÁ H, MAREŠ P, VORLÍČEK J: Stable anticonvulsant action of benzodiazepines during development in rats. J Pharm Pharmacol 45: 807-810, 1993.

KUBOVÁ H, VILÁGI I, MIKULECKÁ A, MAREŠ, P: NonNMDA antagonist GYKI 52466 suppresses cortical afterdischarges in immature rats. Eur J Pharmacol 333: 17-26, 1997.

LOJKOVÁ D, MAREŠ P: Anticonvulsant action of an antagonist of metabotropic glutamate receptors mGluR5 MPEP in immature rats. Neuropharmacology 49: 219-229, 2005.

MAREŠ P: Anticonvulsant action of three neurosteroids against cortical epileptic afterdischarges in immature rats. Brain Res Bull 68: 179-184, 2005.

MAREŠ P, KUBOVÁ H: Electrical stimulation-induced models of seizures, In: Models of Seizures and Epilepsy. PITKANEN A, SCHWARTZKROIN PA, MOSHE SL (eds), Elsevier, Amsterdam 2006, pp.153-159.

MAREŠ P, ŠLAMBEROVÁ R: Efficacy of bretazenil against cortical epileptic aferdischarges increases during early ontogeny in rats. Pharmacol Reports 58: 519-525, 2006a.

MAREŠ P, ŠLAMBEROVÁ R: Opposite effects of a $\mathrm{GABA}_{\mathrm{B}}$ antagonist in two models of epileptic seizures in developing rats. Brain Res Bull 71: 160-166, $2006 \mathrm{~b}$.

MAREŠ P, VELÍŠEK L: N-Methyl-D aspartate (NMDA)-induced seizures in developing rats. Dev Brain Res 65: $185-$ $189,1992$.

MAREŠ P, MIKULECKÁ A, POMETLOVÁ M: Anticonvulsant action of NBQX in immature rats: Comparison with the effects on motor performance. J Pharmacol Exp Ther 281: 1120-1126, 1997.

MAREŠ P, HAUGVICOVÁ R, KUBOVÁ H: Unequal development of thresholds for various phenomena induced by cortical stimulation in rats. Epilepsy Res 49: 35-43, 2002a. 
MAREŠ P, HAUGVICOVÁ R, KUBOVÁ H: Interaction of excitatory amino acid agonists with cortical afterdischarges in developing rats. Epilepsia $\mathbf{4 3}$ (Suppl 5): 61-67, 2002b.

MELDRUM BS, ROGAWSKI MA: Molecular targets for antiepileptic drug development. Neurotherapeutics 4: 18-61, 2007.

MOLDRICH RX, CHAPMAN AG, DE SARRO G, MELDRUM BS: Glutamate metabotropic receptors as targets for drug therapy in epilepsy. Eur J Pharmacol 476: 3-16, 2003.

PETRALIA RS, WENTHOLD RJ: Light and electron immunocytochemical localization of AMPA-selective glutamate receptors in the rat brain. J Comp Neurol 318: 329-354, 1992.

POLÁŠEK R, KUBOVÁ H, ŠLAMBEROVÁ R, MAREŠ P, VORLÍČEK J: Suppression of cortical epileptic afterdischarges in developing rats by anticonvulsants increasing GABAergic inhibition. Epilepsy Res 25: 177184, 1999.

ROGAWSKI MA, LOSCHER W: The neurobiology of antiepileptic drugs. Nature Rev Neurosci 5: 553-564, 2004.

SANCHEZ RM, JENSEN FE: Maturational aspects of epilepsy mechanisms and consequences for the immature brain. Epilepsia 42: 577-585, 2001.

SPREAFICO R, FRASSONI C, ARCELLI P, BATTAGLIA G, WENTHOLD RJ, DE BIASI S: Distribution of AMPA selective glutamate receptors in the thalamus of adult rats and during postnatal development. A light and ultrastructural immunocytochemical study. Dev Brain Res 82: 231-244, 1994.

ŠLAMBEROVÁ R, MAREŠ P: Cortical epileptic afterdischarges in immature rats are differently influenced by NMDA receptor antagonists. Eur J Pharmacol 516: 10-17, 2005.

VOSKUYL RA, DINGMANSE J, DANHOF M: Determination of the threshold for convulsions by direct cortical stimulation. Epilepsy Res 3: 120-129, 1989.

VOSKUYL RA, HOOGERKAMP A, DANHOF M: Properties of the convulsive threshold determined by direct cortical stimulation in rats. Epilepsy Res 12: 111-120, 1992.

WHITE HS, SMITH MD, WILCOX KS: Mechanisms of action of antiepileptic drugs. Int Rev Neurobiol 81: 85-110, 2007. 